\title{
Bringing Bourdieu to Mathematics Education: a response to Williams and Choudry
}

\author{
Andrew Noyes \\ University of Nottingham
}

\begin{abstract}
"to penalize the underprivileged and favour the most privileged, the school has only to neglect, in its teaching methods and techniques and its criteria when making academic judgements, to take into account the cultural inequalities between the different social classes. In other words, by treating all pupils, however unequal they may be in reality, as equal in rights and duties, the educational system is led to give its de facto sanction to initial cultural inequalities. The formal equality which governs pedagogical practice is in fact a cloak for a justification of indifference to the real inequalities with regard to the body of knowledge taught or rather demanded." (Bourdieu, 1974, p. 37)
\end{abstract}

For those engaged in educational 'improvement', it is important to pause from time to time to ask the question: what is improving? If Bourdieu's thesis is correct, namely that education is a key site of social reproduction, does school improvement, and/or improvement of mathematics education, also enhance that capacity for the social reproduction of social class differences? Most teachers, leaders, researchers and politicians would not want this, and would not ordinarily recognise such a process or their contribution to it, but it is an important question nonetheless; one that my colleague Peter Gates and I recently explored in a chapter for teachers: 'School mathematics as social classification' (Gates \& Noyes, 2014, p. 78).

I agree with Williams and Choudry's opening statement that 'mathematics education needs a better appreciation of the dominant power structures in the education field'. Bourdieu has much to offer in this regard. In response to their paper, I will 
address five points, albeit rather briefly : 1) the usefulness of Bourdieu's theory of practice, 2) the problem of language, 3) forms of capital, 4) hope and, finally, 5) going beyond Bourdieu.

\section{Bourdieu's theory of practice}

Bourdieu's theory of practice is tremendously useful for sociologists of (mathematics) education interested in understanding why things are the way they are. We have had a 'social turn' in mathematics education research but there remains an outstanding need for critical investigations of the broader social, cultural and political impact of school mathematics: who gets what? Bourdieu was in part concerned with explaining the mechanisms of social stasis, how it is that social practices and relations tend to get reproduced despite the absence of clearly articulated rules. At the heart of his contribution to the structure-agency debate were the dialectically-related concepts of habitus and field. These are challenging ideas that evolved over Bourdieu's lifetime; linked concepts that have often been partially understood or pulled apart and thereby diminished in power.

Habitus is the "durably installed generative principle of regulated improvisations" (Bourdieu, 1977, p. 78) whilst fields are akin to magnetic force-fields, powerful yet invisible, disruptable yet predictable; defined by "the unequal distribution of capital" (Bourdieu, 1986, p. 246), they are sites of struggle. Suffice to say that Bourdieu's 'theory of practice' (not capital), with its core concepts of field, habitus and capital, offers tools for sociological analysis that many have found to be tremendously helpful, including myself (for example, Noyes, 2006; Noyes, 2007).

Much mathematics education research focuses on decontextualized classrooms or learning episodes, failing to recognise the habitus of individuals, the fields that tend to position them and the forms and flows (or not) of 'capital'. One problem for 
researchers is to define these fields and this is something that needs more thought in the paper and, in my view, mathematics education research more generally. Mathematics (education) is peculiar in its relationship to the fields of science, industry, commerce and, thereby, policy and power. Arguably, it is different subsets of the thing we call 'mathematics' (e.g. basic numeracy, advanced algebra or calculus, quantitative literacy, modelling), that has value (capital) in these spaces, though this is rarely discussed in the literature. Moreover, this capital exists in different forms and so further work is needed to define a particular 'mathematics capital', if indeed the concept works at all. The distinction between practice ('use value') and qualification ('exchange value') is worthy of further consideration, though the binary is both limiting and overly simplistic. These two notions are not, in any straightforward sense, 'contradictory'.

In Bourdieu's analysis of the scientific field he describes a 'series of structural interlockings' (Bourdieu, 2004) and that approach could be productively used for mathematics learners in classrooms, in departments, in schools, in local/national school/employment market, etc. We might also think simultaneously of learners in families, within social milieu. My point, which is explored elsewhere in more detail (Noyes, 2013), is that to observe a classroom is to observe the imbricated structured/structuring layers in/through which learners and teachers are located/acting. These are the accumulation of individual and collective social history interwoven with educational, economic and cultural histories, either embodied in people (children, teachers, parents, etc.) or objectified in things (schools, textbooks, discourses, etc.). Mathematics education researchers could pay more attention to "the extremely complex mechanisms through which the school institution contributes...to the reproduction of the distribution of cultural capital and, consequently, of the structure of social space." (Bourdieu, 1998b, p. 19). Williams and Choudry's contribution is therefore welcomed, 
though it is notable that in their passing discussion of mathematics assessment neither the family nor social milieu featured in their list of what/who was being assessed.

\section{The problem of language}

Bourdieu described his own writing style as "a permanent struggle against ordinary language" (Bourdieu, 1988, p. 149) and advised novice sociologists to "beware of words" as "language poses a particularly acute problem for the sociologist because it carries along a "spontaneous" social philosophy which constitutes one of the most formidable "epistemological obstacles" to a rigorous science of society" (Bourdieu \& Wacquant, 1989, p. 54). His writing style has been criticised but 'common sense' assumptions about language also need sustained challenge.

Although Williams and Choudry recognise this problem, and are on occasions playful with the criticism of obfuscation in Bourdieu's writing, they could perhaps take greater heed to his approach. Terms such as 'mathematics education' and 'use' are deployed as if they mean something clear and straightforward when they do not. The notion of the 'use value' of mathematics is worthy of a book in itself. There are further instances of casual, ordinary language, for example when they write of the 'elegance and beauty of good mathematics'. This phrase belies a set of arbitrary cultural values regarding what counts in school mathematics, which is ironic given their interest in exposing and critiquing arbitrary values.

\section{'The forms of capital'}

Williams and Choudry discuss in some detail the notions of 'use' and 'exchange' value that arose from the earlier programme of work at Manchester. These are helpful ideas but again they suffer from being words with complex/multiple meanings that demand careful explication. The two ideas refer to quite different forms of capital. In 'The 
forms of capital' (Bourdieu, 1986) qualifications are considered an institutionalized form of cultural capital (in contrast to the embodied and objectified forms). Their institutionalized form allows for generalized exchange between cultural and economic capital in the labour market. Indeed, there is good evidence that mathematics qualifications are associated with economic wage returns (Adkins \& Noyes, 2015; Dolton \& Vignoles, 2002) and great play has been made of this by politicians (Noyes \& Adkins, 2015). It is harder to say whether or not the return is due to a (mathematical) social hierarchy or an embodied cultural capital, i.e. some mathematical skills that are a) durable and b) genuinely useful and valuable in practice - 'use value'. Similarly, the association of poor numeracy with unemployability has been made (Bynner \& Parsons, 1997), though it is easier to see that the absence of 'basic skills' would matter for employers; a point which is regularly made by the likes of the Confederation of British Industry.

In my earlier work (Sealey \& Noyes, 2010) two groups of students had very different understandings of the exchange value of mathematics qualifications based upon their aspirations and social class. We considered four types of relevance or value for school mathematics (practical, process, professional, and political) which bear some relation to 'use' and 'exchange' (and critical mathematics). The key distinction between the communities in the research was that the affluent suburban students sidelined the notion of 'use' because they understood the powerful exchange value of mathematics qualifications for accessing high status careers; mathematics opens doors.

\section{Hope}

Bourdieu might be considered an 'emancipatory pessimist'; he critiques inequality and advocates social transformation whilst recognising the tendency for social stasis and the effectiveness of the strategies of the powerful that maintain their interests and positions. 
As one of the great public intellectuals of the late $20^{\text {th }}$ century, he championed a range of social justice concerns (e.g. Bourdieu, 1998a). However, he was also realistically aware of the tendency for social classificatory systems to resist attempts to transform them. For this reason, his work has come in for some criticism.

Williams and Choudry's brief foray into critical pedagogy explores the question of whether alternative approaches to mathematics might enable a break from, or at least a challenge to, any socio-reproductive function of school mathematics. The extent to which this is possible is a moot point, as are the necessary conditions for such a move. Skovsmose argues that "if we see mathematics education as part of universal processes of globalisation, then we should also see it as part of the universal processes of making exclusions" (2005, p. 38). Arguably, this process happens at all scales of formal mathematics education; from within classrooms to between national education systems. Elsewhere, motivated by similar concerns, Gutstein (2006, quoting Morrell) argues that it is important to balance a 'pedagogy of access' (i.e. getting the qualifications needed for success - i.e. exchange) and a 'pedagogy of dissent' (i.e. critical mathematics). Using mathematics to 'read and write the world' (following Freire) is not straightforward but explicitly aims to deploy mathematics to expose and critique inequity. It seems unlikely that more critical mathematics will challenge the gatekeeping role (Volmink, 1994) of mathematics.

One cannot ignore the powerful 'exchange value' of mathematics qualifications, or indeed the market value placed on the high-level mathematical skills needed for certain commercial, technological and scientific roles. At the same time, if one takes Heymann's (2003) argument that the mathematics that most people need is already acquired (though evidently not mastered) by the end of primary school, the question of 
who is best served by existing curricula and commonplace pedagogies come sharply into focus; a point well made in the quote from Bourdieu at the start of this paper.

\section{Going beyond Bourdieu}

Williams and Choudry would like to go 'beyond Bourdieu' and the key reason for doing so is their claim that Bourdieu's notion of capital is in some sense deficient in the context of mathematics education, and therefore needs extending. Exchange and use are different kinds of value/capital, as discussed above. Moreover, they are not unrelated; that which enables qualifications success (exchange value) is associated with - in some complex way - what can be done (use value). Qualifications are more straightforward to understand and 'exchange' than are a myriad of people mathematics usages. There is also the danger that the general, abstracted usefulness of mathematics itself is elided with the usefulness of a particular individual's mathematical competence. I am not suggesting that mathematics is not useful, either in itself or to individuals. Rather, that the idea of 'use value' needs further development, and a great deal more empirical work, before deciding whether one needs to go 'beyond Bourdieu' for theoretical explanations.

There is much more work to do with Bourdieu's sociological toolkit, particularly developing analyses of field and capital in the context of mathematics education. This might be undertaken in the context of classrooms, or on the multi-scaled field of mathematics education and those other fields with which it intersects. The structural interlockings of mathematics, science, (education) policy, schools, industry, etc. would be worth exploring in all of their complexity. The context of the Manchester programme is upper secondary and into $\mathrm{FE} / \mathrm{HE}$ where multiple fields intersect making the analysis more complex, more interesting and necessary. Indeed, it might be the case 
that more sustained (Bourdieuan) analyses of such interfaces would help to explicate the notion of use value more fully.

There is plenty more interesting work to be done about the field of mathematics education (which is not the same as the field of mathematics, though it intersects). It would also be worth exploring other key Bourdieuan ideas such as symbolic violence and the mechanisms through which many young people experience the 'psychological brutality' of the mathematics classroom. So, I would caution against going beyond Bourdieu just yet. If his tools offer a means of mapping the landscape of mathematics education then there remains a lot of unchartered territory, and it might well be the case that an adequate theorisation of Williams and Choudry's 'use value' and other concerns can be made without 'going beyond'.

\section{References:}

Adkins, M., \& Noyes, A. (2015). Reassessing the economic value of Advanced level Mathematics. British Educational Research Journal, in press.

Bourdieu, P. (1974). The school as a conservative force: scholastic and cultural inequalities. In J. Egglestone (Ed.), Contemporary research in the sociology of education (pp. 32-46). London: Methuen \& Co Ltd.

Bourdieu, P. (1977). Outline of a Theory of Practice. Cambridge: Cambridge University Press.

Bourdieu, P. (1986). The Forms of Capital. In J. G. Richardson (Ed.), Handbook of Theory and Research for the Sociology of Education (pp. 241-258). New York: Greenwood Press.

Bourdieu, P. (1988). Homo Academicus (P. Collier, Trans.). Cambridge: Polity Press.

Bourdieu, P. (1998a). Acts of Resistance (R. Nice, Trans.). Cambridge: Polity Press.

Bourdieu, P. (1998b). Practical Reason. Cambridge: Polity Press.

Bourdieu, P. (2004). Science of Science and Reflexivity. Chicago: The University of Chicago Press.

Bourdieu, P., \& Wacquant, L. (1989). Toward a reflexive sociology: a workshop with Pierre Bourdieu. Sociological Theory, 7(1), 26-63.

Bynner, J., \& Parsons, S. (1997). Does Numeracy Matter? Evidence from the National Child Development Study on the Impact of Poor Numeracy on Adult Life. London: Basic Skills Agency.

Dolton, P., \& Vignoles, A. (2002). The return on post-compulsory school mathematics study. Economica, 69(273), 113-142.

Gates, P., \& Noyes, A. (2014). School mathematics as social classification. In D. Leslie \& H. Mendick (Eds.), Debates in Mathematics Education (pp. 38-48).

Abingdon: Routledge. 
Gutstein, E. (2006). Reading and Writing the World with Mathematics: Toward a Pedagogy for Social Justice. New York: Routledge.

Heymann, H. W. (2003). Why Teach Mathematics: a focus on general education. Dordrecht: Kluwer Academic Publishers.

Noyes, A. (2006). School Transfer and the Diffraction of Learning Trajectories. Research Papers in Education, 21(1), 43-62.

Noyes, A. (2007). Mathematical Marginalisation and Meritocracy: inequity in an English classroom. In B. Sriraman (Ed.), International Perspectives on Social Justice in Mathematics Education. (Vol. , pp. 35-48). Missoula MT: University of Montana Press.

Noyes, A. (2013). Scale in education research: towards a multi-scale methodology. International Journal for Research and Method in Education, 36(2).

Noyes, A., \& Adkins, M. (2015). The impact of education research upon policy: a case study. Submitted to the British Journal of Educaitonal Studies.

Sealey, P., \& Noyes, A. (2010). On the relevance of the mathematics curriculum to young people. Curriculum Journal, 21(3), 239-253.

Skovsmose, O. (2005). Travelling through Education. Rotterdam: SensePublishers.

Volmink, J. (1994). Mathematics By All. In S. Lerman (Ed.), Cultural Perspectives on the Mathematics Classroom (Volume 14 ed.). Dortrecht: Kluwer Academic Publishers. 